\title{
Kyphosis in Barbus pergamonensis (Cyprinidae-Actinopterygii) from Dalaman Stream Flowing to the Mediterranean Sea
}

\author{
Deniz Innal ${ }^{\star *}$ (D), Evsen Yavuz Guzel ${ }^{2}$ (D), Omer Gürkan Dilek ${ }^{3}$ (D), Seyit Ali Kamanli ${ }^{1}$ (])
}

Cite this article as: Innal, D., Yavuz-Guzel, E., Dilek, O. G., \& Kamanli, S. A. (2019). Kyphosis in Barbus pergamonensis (Cyprinidae-Actinopterygii) from Dalaman Stream Flowing to the Mediterranean Sea. Aquatic Sciences and Engineering, 34(2), 39-45.

ORCID IDs of the authors: D.I. 0000-0002-1686-0959; E.Y.G. 0000-0002-8029-9254 O.G.D. 000-0002-5717-3928; S.A.K. 0000-0002-9118-4591

'Burdur Mehmet Akif Ersoy University, Department of Biology, Burdur, Turkey

${ }^{2}$ Çukurova University, Fisheries

Faculty, Basic Sciences

Department, Balcalı-Adana,

Turkey

${ }^{3}$ Burdur Mehmet Akif Ersoy University, Faculty of Veterinary

Medicine, Department of

Anatomy, Burdur, Turkey

Submitted:

27.03.2019

Revision Requested

26.04.2019

Last Revision Received 06.05.2019

Accepted:

12.05.2019

Online published:

24.05.2019

Correspondence:

Deniz Innal

E-mail:

innald@yahoo.com

(C) Copyright 2019 by Aquatic

Sciences and Engineering

Available online at

https://dergipark.org.tr/ase

\begin{abstract}
Skeletal deformities are relatively well described in both cultured and wild fish. These diseases are observed in many fish species and occur due to environmental and genetic factors. It negatively affects the biological performance and commercial value of fish. For this reason, this study attempts to quantify and identify kyphosis in the natural populations of Barbus pergamonensis Karaman, 1971 collected from Dalaman Stream (Gölhisar/Burdur) and tends to find a possible relationship between these anomalies and several types of pollutants present in the environment. The current study found that the environmental pollutants may represent a potential risk to induce kyphosis in the natural populations of B. pergamonensis.
\end{abstract}

Keywords: Bergama barbel, pollution, skeletal deformities, pharmaceutical, pesticide

\section{INTRODUCTION}

It is widely known that many anatomical diseases occur in fish due to the environmental and genetic factors (Jawad \& Ibrahim, 2018). In recent decades, fishery biologists have become more interested in skeletal deformity diseases of wild and reared fish (Kužir et al., 2015). Many types of deformities (Afonso et al., 2000; Sato, 2006; Jawad et al., 2017; Jawad \& Ibrahim, 2018) have been reported from the variety of fish species living in the different habitats (Iwasaki et al., 2018). It was reported that these deformities affect mostly the ribs, fins, cranium and vertebral column of fish (De La Cruz-Aguero \& Perezgomez-Alvarez, 2001). These diseases have negative effects on the biological performance of fish as well as decreasing the commercial value (Raja et al., 2016; Majeed et al., 2018). In wild fish, skeletal deformities that occur in any life stage of fish can cause them difficulties such as defending their territory (Sato, 2006; Majeed et al., 2018), competing for a mate (Sato, 2006), and decreasing production performance (Noble et al., 2012). In farmed fish, these injuries can affect the organism by reducing growth (Hansen et al., 2010), limiting their feeding ability (López-Olmeda et al., 2012; Okamura et al., 2018), increasing the infection (Janakiram et al., 2018) and mortality rate (Jara et al., 2017). Moreover, these negative effects of the skeletal deformities inevitably cause reasonable economic loss in the fish farms (Boglione, 2013a; Yıldırım et al., 2014).

There are a variety of reasons for the occurrence of the skeletal deformities in fish. These are mostly known as scolosis, spondylolisthesis, lordosis (dorsal curvature, $v$ shape), and kyphosis (ventral curvature, $\wedge$ shape (Yıldırım et al., 2014; Jawad et al., 2017). Although there are many reports of lordosis (Afonso et al., 2000; Fjelldal et al.,2009; Gorman et al., 2010), the rate of occurrence of kyphosis is less common than lordosis (Jawad et al., 2017). Like lordosis, kyphosis can also appear in both pre-haemal and haemal positions (Boglione et al., 2013a). All these deformities are linked to genetic and epigenetic factors (Nguyen et al., 2016). Some environmental parameters, such as salinity, sud- 
den changes of water temperature and turbulence, oxygen content, organic compounds, radiation, heavy metals, industrial effluents, stress, food deficiency, parasitism (Dionísio et al., 2012; Fridman et al., 2012; Kolarevic et al., 2013) and pollution are among the most considerable epigenetic factors (Sfakianakis et al., 2006). In addition, pollution is considered as a useful index for evaluation of the frequency of deformities in fish (Boglione et al., 2013b).

Bergama barbel, Barbus pergamonensis Karaman, 1971, belonging the family Cyprinidae is a freshwater fish species distributed in the fresh waters of Turkey and Greece (Kottelat \& Freyhof, 2007). The distribution areas of this fish in Turkey are reported to be from the Aegean drainages, the Bakır and Menderes Rivers and the drainages of Muğla (Kottelat \& Freyhof, 2007). Barbus pergamonensis was reported as being heavily affected by agricultural activities, domestic and industrial pollution from the industry (Freyhof \& Kottelat, 2018). Therefore, the aim of this study is to identify and quantify the skeletal deformities of $B$. pergamonensis collected from Dalaman Stream (Gölhisar/Burdur/Turkey) as well as finding a possible relationship between the deformities of this species and several types of pollutants that occur in this region.

\section{MATERIAL AND METHODS}

\section{Specimen collection}

The individuals of $B$. pergamonensis ranging from $3.5 \mathrm{~cm}$ to 20 $\mathrm{cm}$ were collected from the Dalaman Stream from three different stations [1-) $37^{\circ} 13^{\prime} 36.53^{\prime \prime} \mathrm{N}, 29^{\circ} 32^{\prime} 57.66^{\prime \prime} \mathrm{E}$; 2-) $37^{\circ} 14^{\prime} 39.39^{\prime \prime} \mathrm{N}$,

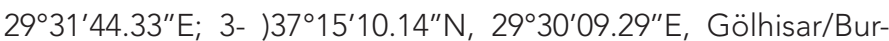
dur/ Turkey] between June 2015 and June 2016. In total, 54 individuals were caught after seven sampling events carried out using electrofishing. All fish samples used in the current study were anaesthetized with MS-222. Fish samples were fixed in 4\% formaldehyde solution and then deposited in 70\% ethanol in the fish collection of the Ichthyology Laboratory at the Department of Biology, Burdur Mehmet Akif Ersoy University. Specimens were measured to the nearest $0.1 \mathrm{~cm}$ for standard length (SL) and weighed to the nearest $0.001 \mathrm{~g}$ for body weight.

\section{X-ray treatment}

In order to determine skeletal deformities of specimens, the fresh fish samples were individually $x$-rayed using a Fujifilm FCR Prima T®-Tokyo, Japan at Burdur Mehmet Akif Ersoy University, Faculty of Veterinary Clinics. Specimens were x-rayed at the exposure time $100 \mathrm{kVp}, 30 \mathrm{mAs}, 3$ second from the lateral positions of each sample to demonstrate the exact nature of the deformities.

Non-metallic inorganic parameters, dissolved metals, pharmaceutical and pesticide analysis in water samples

Many chemical parameters of Dalaman Stream were also analysed in order to determine the relationship between the pollution and kyphosis occurring in fish in the studied area. These includes non-metallic parameters, dissolved metals, pharmaceutical compounds from variety of drug groups and pesticides. Non-metallic inorganic parameters and dissolved metals shown in Table 1 were analysed in ALS Laboratory in Czechia. All meth- ods used for the analysis of non-metallic inorganic parameters and dissolved metals/ major cations were shown in Table 1. Solid phase extraction (SPE) and liquid chromatography tandem mass spectrometry (LC-MS/MS) were used for the pesticide and pharmaceutical analyses.

For pharmaceutical analysis, $1 \mathrm{~L}$ surface water sample was filtered using glass fibre filters (GF/F, Whatman). After filtration, samples were adjusted to $\mathrm{pH} 2$ with $\mathrm{H}_{2} \mathrm{SO}_{4}$ (98wt \%). Then, solid phase extraction was conducted for pharmaceutical analysis using the method of Guzel et al. (2018). First, internal standard diazepam-d5 were added to the water samples. Then, Oasis HLB cartridges $(500 \mathrm{mg}, 6 \mathrm{cc}$ ) were conditioned with $5 \mathrm{ml}$ dichloromethane (DCM), $5 \mathrm{ml}$ methyl tert-butyl ether (MTBE), $5 \mathrm{ml}$ methanol $(\mathrm{MeOH})$ and $5 \mathrm{ml}$ ultrapure water. Water samples were then added to the SPE cartridge at a flow rate of $15 \mathrm{ml} / \mathrm{min}$ and it was washed with $5 \mathrm{ml}$ ultrapure water. Next, sample loading cartridges were dried under vacuum for 1 hour. Eluent was taken with 5 $\mathrm{ml}$ of $\mathrm{MeOH}$ and $5 \mathrm{ml}$ 10:90 (v/v) MeOH/MTBE. The eluent was dried with nitrogen and then dissolved with $1 \mathrm{ml} \mathrm{MeOH}$. Extracted samples were analysed by using LC/MS-MS

Solid phase extraction for pesticide analysis was made by using modified method of Hladik et al. (2008). Internal standard dimethoate-d6 were added to the $1 \mathrm{~L}$ water samples. Oasis HLB cartridges $(500 \mathrm{mg}, 6 \mathrm{cc}$ ) were conditioned with $10 \mathrm{~mL}$ eth$\mathrm{yl}$ acetate, $10 \mathrm{~mL} \mathrm{MeOH}$ and $5 \mathrm{~mL}$ of ultrapure water. Water samples added to the SPE cartridge at a flow rate of $10 \mathrm{ml} / \mathrm{min}$. Then, samples were loaded to cartridges and it was dried under vacuum for 1 hour. Eluent was taken with $12 \mathrm{ml}$ of ethyl acetate. The eluent was dried with nitrogen and then dissolved with $1 \mathrm{ml} \mathrm{MeOH}$. Extracted samples were analysed by using LC/MS-MS.

Instrumental analysis was performed with Shimadzu CBM-20A ultra flow liquid chromatography, Shimadzu SIL-20A/HT auto sampler system and Shimadzu 8040 mass spectrometry. Pharmaceutical compounds were separated using pentafluorophenylpropyl (PFPP) column (Allure 50x2.150 mm, 5 $\mathrm{m}$, Restek, Bellefonte, PA, USA) and pesticide compounds were separated by using Shimpack Column, FC-ODS 150X2.0 mm, Kyoto, Japan. Pharmaceutical and pesticide compounds were detected with multiple reactions monitoring (MRM) mode. Total run time for pharmaceutical method and pesticide method were 18 and 20 minutes respectively.

\section{RESULTS AND DISCUSSION}

\section{The skelatal deformities of the fish samples}

The spinal curvature (kyphosis) was found in two (3.7\%; A and B in Figures 1,2) out of 54 adult fish sampled from three different stations in Dalaman Stream. The Standard length (SL) of these two samples were measured as $12.3 \mathrm{~cm}(\mathrm{~A})$ and $12.1 \mathrm{~cm}(B)$ respectively (Fig. 1 and 2). In fish A, the vertebral anomaly was found between 17 and 47 vertebrae. Whereas the spinal anomaly was involved between 16 and 32 vertebrae in fish B. Although kyphosis in the caudal vertebrae of both samples were diagnosed, no external lesions were observed on these body of deformed specimens. 


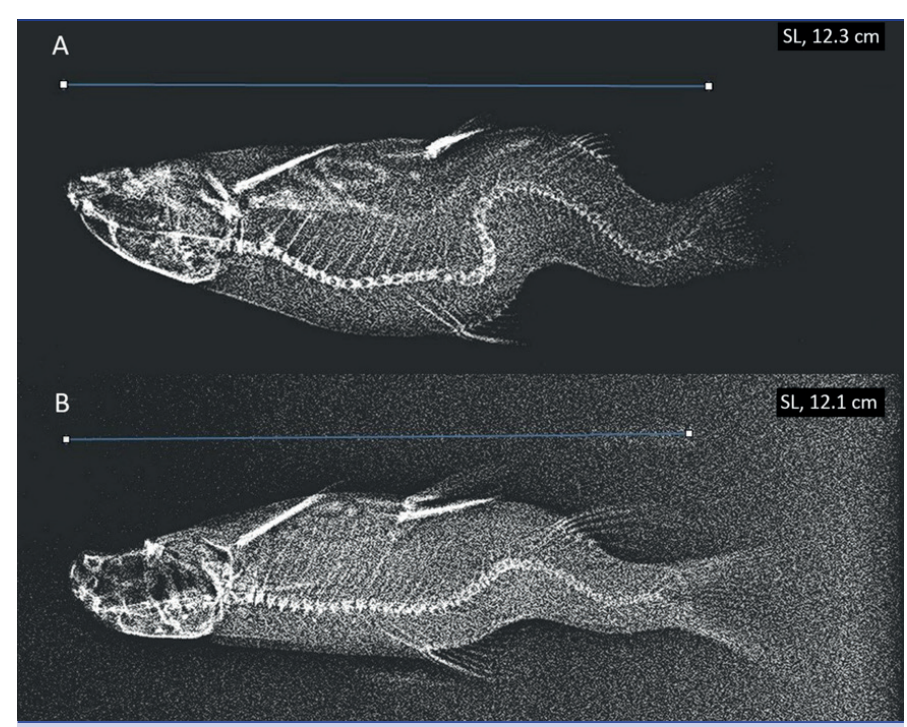

Figure 1. Radiological images of two Barbus pergamonensis samples diagnosed with kyphosis; (A) $12.3 \mathrm{~cm}$ $\mathrm{SL} ;$ (B) $12.1 \mathrm{~cm} \mathrm{SL}$.

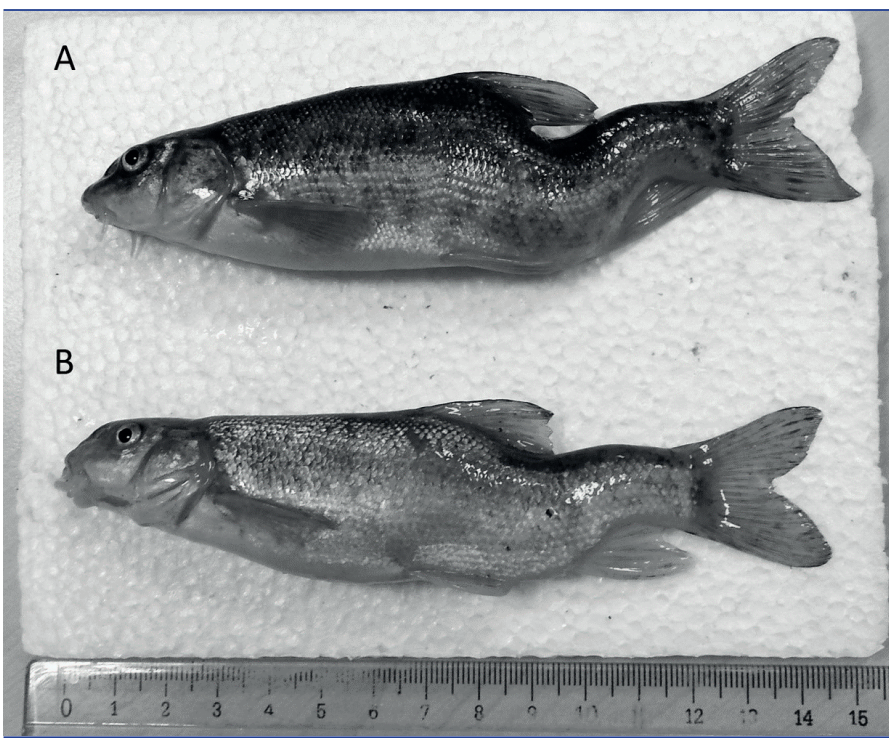

Figure 2. Photography images of two Barbus pergamonensis samples diagnosed with kyphosis; (A) 12.3 $\mathrm{cm} \mathrm{SL;} \mathrm{(B)} 12.1 \mathrm{~cm} \mathrm{SL}$.

Determining the chemicals, pharmaceutical and pesticide in water samples

Non-metallic inorganic parameters and dissolved metals are given in Table 1.

In the current study, 10 out of 14 non-metallic parameters and 11 out of 26 dissolved metals were found higher than normal values (see Table 1). 156 pharmaceutical compounds from variety of drug groups including painkillers (analgesics, anti-inflammatories and antipyretics), antibiotics, andantibacterials, cardiovascu-

\section{Pharmaceutical Concentrations}

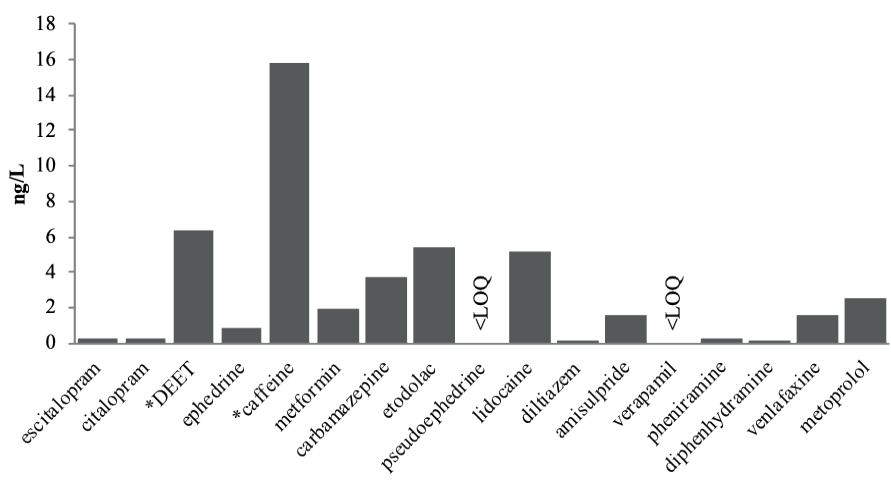

Figure 3. Pharmaceutical concentrations of water samples (DEET and caffeine concentrations reduced 10 times, <LOQ: Lower than quantitation limit).

\section{Pesticide Concentrations}

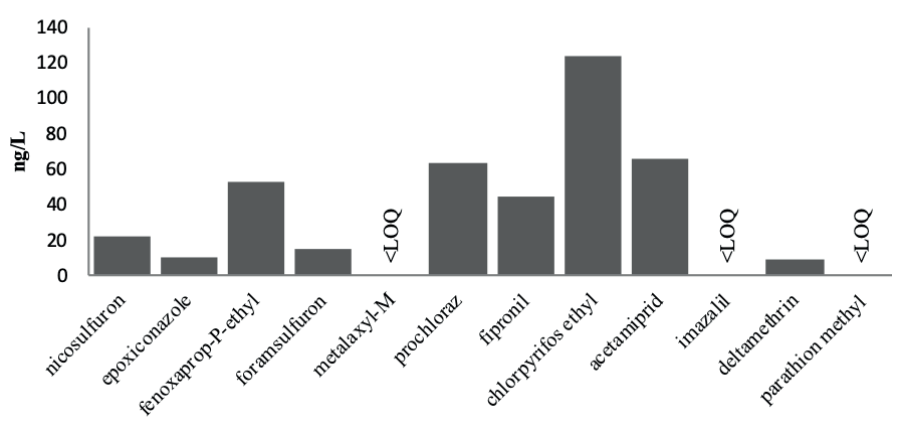

Figure 4. Pesticide concentrations of water samples (<LOQ: Lower than quantitation limit).

lar drugs (B-blockers), hipolipidemics, central nervous system drugs, stimulants and illicit drugs were investigated in water samples. 17 of these pharmaceuticals (escitalopram, citalopram, DEET, ephedrine, caffeine, metformin, carbamazepine, etodolac, pseudoephedrine, lidocaine, diltiazem, amisulpride, verapamil, pheniramine, diphenhydramine, venlafaxine, metoprolol) were detected in $\mathrm{ng} / \mathrm{L}$ values (Fig. 3).

In addition, 144 pesticides that include herbicides, insecticides, acaricides, fungicides were analysed and 12 of them (nicosulfuron, epoxiconazole, fenoxaprop-P-ethyl, foramsulfuron, metalaxyl-M, prochloraz, fipronil, chlorpyrifos ethyl, acetamiprid, imazalil, deltamethrin, parathion methyl) were detected in the water samples (Fig. 4).

The results of non-metallic inorganic parameters were given in Table 1. Ammonia and ammonium ions as N, ammonia and ammonium ions as $\mathrm{NH} 4$ and nitrite as $\mathrm{N}$ were found lower than method detection limits. According to Turkey Surface Water Quality Regulations, nitrates and total kjeldahl nitrogen as $\mathrm{N}$ concentrations were found as 2 nd grade water quality (less 
Table 1. Non-metallic and dissolved metals inorganic parameters

\begin{tabular}{|c|c|c|c|c|}
\hline No & Parameter & $\begin{array}{l}\text { Limit of reporting }(\mathrm{mg} / \mathrm{l}) \\
\text { (LOQ) }\end{array}$ & Method & Result (mg/l) \\
\hline \multicolumn{5}{|c|}{ Nonmetallic Inorganic Parameters } \\
\hline 2 & Ammonia and ammonium ions as $\mathrm{NH} 4$ & 0.050 & W-NH4-SPC & $<\mathrm{LOQ}$ \\
\hline 3 & Chloride & 1.00 & W-CL-IC & 568 \\
\hline 6 & Nitrite + Nitrate as $\mathrm{N}$ & 0.060 & W-NNO-SPC & 0.876 \\
\hline 7 & Nitrites & 0.0050 & W-NO2-SPC & $<\mathrm{LOQ}$ \\
\hline 8 & Organic Nitrogen as N & 0.50 & W-NORG-SPC & 0.70 \\
\hline 9 & Orthophosphate & 0.040 & W-PO4O-SPC & 0.049 \\
\hline 10 & Total Kjeldahl Nitrogen as N & 0.50 & W-NKJ-PHO & 0.70 \\
\hline 14 & Orthophosphate as P & 0.010 & W-PO4O-SPC & 0.016 \\
\hline \multicolumn{5}{|c|}{ Dissolved Metals / Major Cations } \\
\hline 1 & Aluminium & 0.010 & W-METAXFL1 & $<\mathrm{LOO}$ \\
\hline 2 & Antimony & 0.010 & W-METAXFL1 & $<\mathrm{LOO}$ \\
\hline 3 & Arsenic & 0.0050 & W-METAXFL1 & $<\mathrm{LOQ}$ \\
\hline 4 & Barium & 0.00050 & W-METAXFL1 & 0.0243 \\
\hline 5 & Beryllium & 0.00020 & W-METAXFL1 & $<\mathrm{LOQ}$ \\
\hline 6 & Boron & 0.010 & W-METAXFL1 & 0.016 \\
\hline 7 & Cadmium & 0.00040 & W-METAXFL1 & $<\mathrm{LOQ}$ \\
\hline 15 & Magnesium & 0.0030 & W-METAXFL1 & 31.9 \\
\hline 16 & Manganese & 0.00050 & W-METAXFL1 & $<\mathrm{LOQ}$ \\
\hline 17 & Molybdenum & 0.0020 & W-METAXFL1 & $<\mathrm{LOQ}$ \\
\hline 18 & Nickel & 0.0020 & W-METAXFL1 & 0.0039 \\
\hline 19 & Phosphorus & 0.010 & W-METAXFL1 & 0.025 \\
\hline 20 & Potassium & 0.015 & W-METAXFL1 & 1.43 \\
\hline 21 & Selenium & 0.010 & W-METAXFL1 & $<\mathrm{LOQ}$ \\
\hline 22 & Silver & 0.0010 & W-METAXFL1 & $<\mathrm{LOO}$ \\
\hline 23 & Sodium & 0.030 & W-METAXFL1 & 6.66 \\
\hline 24 & Thallium & 0.010 & W-METAXFL1 & $<\mathrm{LOO}$ \\
\hline 25 & Vanadium & 0.0010 & W-METAXFL1 & 0.0022 \\
\hline 26 & Zinc & 0.0020 & W-METAXFL1 & $<\mathrm{LOO}$ \\
\hline
\end{tabular}

contaminated water) (Anonymous, 2016). And total nitrogen as $\mathrm{N}$ and orthophosphate as $\mathrm{P}$ concentrations were found as $1 \mathrm{st}$ grade water quality (high quality water). But for the ECE (Economic Commission for Europe) Standard Statistical Classification of Surface Freshwater Quality for the Maintenance of
Aquatic Life total nitrogen as $\mathrm{N}$ was found as class IV (UNECE, 1994)

Twenty-six metals and major cations were analysed in water samples (Table 1). Most of the detected metals and major cations 
were lower than the quantification limits. According to ECE Standard Statistical Classification of Surface Freshwater Quality for the Maintenance of Aquatic Life only chromium was classified as class II, the other quantified metals were classified as class I.

To the best of our knowledge, a few biological studies (Gaygusuz et al., 2013; Erk'akan et al., 2014) have been conducted on this species (Freyhof \& Kottelat, 2018). Kyphosis which is a skeletal deformity of fish was studied by many researchers (Hansen et al., 2010; Boglione et al., 2013a; Hayes et al, 2013; Jawad \& Ibrahim, 2018). In addition, there are some reports on kyphosis in cyprinid species from different regions (Bogutskaya et al., 2011). The adverse effects of skeletal deformities on the fish health and economy were also reported in detail in the previous studies (Yıldırım et al., 2014; Nguyen et al., 2016). In recent years, although the number of studies on wild and cultured fish health have been increasing in Turkey, there are limited studies on the skeletal deformities of fish such as cultured sharpsnout seabread Diplodus puntazzo (Yıldırım et al., 2014) and silverside Atherina boyeri (Jawad et al., 2017). In the current study, kyphosis was detected in the Barbus pergamonensis population of Dalaman Stream. It is the first study that kyphosis was detected in the wild population of this fish. In addition, there is no kyphosis report from other fish species from Dalaman Stream.

Previous reports discussed the reasons of skeletal deformities which are genetic and environmental factors (Quigley, 1995, Divanach et al., 1996; Divanach et al., 1997; Sfakianakis et al. 2006; Harris et al., 2014). Micropollutants in the aquatic habitats is one of the major issues worldwide (Eggen et al., 2014). These micropollutants have based on the anthropogenic effects, such as pharmaceuticals, pesticides, personal care products and industrial chemicals (Luo et al., 2014). It is known that all these micropollutants have toxic effects on aquatic species (Morasch et al., 2010; Pochodylo \& Helbling, 2015; Minguez et al., 2016). Aquatic communities can be dramatically affected by the cocktail of low concentrations of micropollutants (Morash et al., 2010). The effects of cocktail micropollutants can be much higher than the effect of a single micropollutant.

In the current study, the relationship between B. pergamonensis and anthropogenic factors occurred in the habitat of this species were emphasised. The pollution effecting the aquatic environment has also been increasing in Turkey with the rising industrialisation and other reasons (Deniz Innal Pers. Obs.). In the study area of the current research, these reasons can be referred for many reasons. First, the studied area has been used as a cultivated area for the production of carrot, sugar beet, maize, green beans and wheat. In order to maintain the agricultural activities in the region, the local people and industries are using variety of chemicals (Deniz Innal Pers. Obs.). Another reason for the pollution can be the treatment facilities in the area. It was observed that the discharge of a treatment facility has been performing via Dalaman Stream. Furthermore, it was detected that the waste from the marble factory and other mining facilities have been carried to this aquatic system. The road construction on the highway between Gölhisar and Çavdır changed the structure of Dalaman Stream. Moreover, the construction of a reservoir on the system for the aim of irrigation has also adverse effect on this prob- lem. The last two reasons caused the decrease of water flow of Dalaman Stream.

In this study, pollution parameters in the studied area have been detected in detail. In total, 17 pharmaceutical and 12 pesticide concentrations were found over the threshold values. Caffeine as a pharmaceutical concentration was detected at the highest concentration (158.51 ng / L). Caffeine concentration is newly used as an anthropogenic effect indicator. Because caffeine is used only by humans (Sauvé et al., 2012). Similarly, in some studies, the concentration of caffeine was found to be in the highest concentrations (Yu \& Cao, 2016; Guzel et al., 2018). When considered the caffeine level found in the current study, it can be supposed that the anthropogenic effect plays a main role for this reason. Whereas the highest concentrated pesticide was detected as chlorpyrifos ethyl (123.40 ng/L). One of the most frequently detected compounds was the specific metabolite of chlorpyrifos in wastewaters which indirectly and/or directly reaching to surface waters (Gracia-Lor et al., 2017). These pesticides are sold from different companies which is mainly used to eradicate several pests including worms and insects. Pesticide usage is highly toxic for the non-target organisms such as fish (Ogunfowokan, et al., 2012; Qu, et al., 2011). Ecotoxicological studies show that such pollutants can cause undesirable effects on fish even at very low concentrations (Faggiano et al., 2010; Ogunfowokan et al., 2012). These kind of detrimental effects of kyphosis can result in death of fish species through impaired metabolism. In the study, the detected pharmaceutical, pesticide and inorganic compound concentrations were low but there may be negative effects on the living organisms when all the substances are present at the same time in the water.

\section{CONCLUSIONS}

Environmental pollutants may represent a potential risk to induce spinal deformities in natural populations of $B$. pergamonensis. As a result, the incresing pollution and the detrimental chemical contents releasing from the differet systems to Dalaman Stream should be firmly decreased in order to prevent the health problems of the aquatic organism living in the region. Furthermore, the emergent skelatal deformities of $B$. pergamonensis and potentially other fish species living in the region seem to be a serious problem for the future of aquatic organisms in Dalaman Stream. Consequently, the further studies should focus on the prevention of these deformities and the main reasons of these health problems in detail.

Acknowledgements: We acknowledge the two anonymous reviewers for their time, considerations and comments which improved this paper.

Ethics Committee Approval: This study was carried out in accordance with animal welfare and the ethics of trial. All procedures were performed in accordance Law on Veterinary and Medical Activities and National Animal Welfare Act. Therefore ethical approval was not required.

Conflict of Interests: Authors declare that there is no conflict of interest. 


\section{REFERENCES}

Afonso, J. M., Montero, D., Robaina, L., Astorga, N., Izquierdo, M. S. \& Gińes, R. (2000). Association of a lordosis-scoliosis-kyphosis deformity in gilthead seabream (Sparus aurata) with family structure. Fish Physiology and Biochemistry 22, 159-163. [CrossRef]

Anonymous. (2016). Yüzeysel su kalitesi yönetimi yönetmeliğinde değişiklik yapilmasina dair yönetmelik, http://www.resmigazete.gov. tr/eskiler/2015/04/20150415-18.htm (Access Date: 2 May 2019).

Boglione, C., Gavaia, P., Koumoundouros, G., Gisbert, E., Moren, M., Fontagné, S. \& Witten, P. E. (2013a). Skeletal anomalies in reared European fish larvae and juveniles. Part 1: Normal and anomalous skeletogenic processes. Reviews in Aquaculture 5, 99-120. [CrossRef]

Boglione, C., Gisbert, E., Gavaia, P., Witten, P. E., Moren, M., Fontagné, S. \& Koumoundouros, G. (2013b). Skeletal anomalies in reared European fish larvae and juveniles. Part 2: main typologies, occurrences and causative factors. Reviews in Aquaculture 5, 121167. [CrossRef]

Bogutskaya, N. G., Zuykov, M. A., Naseka, A. M. \& Anderson, E. B. (2011). Normal axial skeleton structure in common roach Rutilus rutilus (Actinopterygii: Cyprinidae) and malformations due to radiation contamination in the area of the Mayak (Chelyabinsk Province, Russia) nuclear plant. Journal of Fish Biology 79, 991-1016. [CrossRef]

De La Cruz-Aguero, J. \& Perezgomez-Alvarez, L. (2001). Lordosis in topsmelt Atherinops affinis (Ayers, 1860) (Teleostei: Atherinopsidae). Revista De Biologia Marina Y Oceanografia 36(1), 109-110. [CrossRef]

Dionísio, G., Campos, C., Valente, L. M. P., Conceição, L. E. C., Cancela, M. L. and Gavaia, P. J. (2012). Effect of egg incubation temperature on the occurrence of skeletal deformities in Solea senegalensis. Journal of Applied Ichthyology 28, 471-476. [CrossRef]

Divanach, P., Boglione, C., Menu, M., Koumoundouros, G., Kentouri, M. \& Cataudella, S. (1996). Abnormalities in finfish mariculture: an overview of the problem, causes and solutions. Sea-bass and Sea Bream Culture: Problems and Prospects, Verona, Italy, October 1618. European Aquaculture Society, Oostende, Belgium 45-66.

Divanach, P., Papandroulakis, N., Anastasiadis, P., Koumoundouros, G. \& Kentouri, M. (1997). Effect of water currents on the development of skeletal deformities in sea bass (Dicentrarchus labrax L.) with functional swimbladder during postlarval and nursery phase. Aquaculture 156, 145-155. [CrossRef]

Eggen, R. I., Hollender, J., Joss, A., Schärer, M. \& Stamm, C. (2014). Reducing the Discharge of Micropollutants in the Aquatic Environment: The Benefits of Upgrading Wastewater Treatment Plants. Environmental Science \& Technology 48, 7683-7689. [CrossRef]

Erk'akan, F., Innal, D. \& Özdemir, F. (2014). Length-weight relationships for five Cyprinid species in Turkey. Journal of Applied Ichthyology 30, 212-213. [CrossRef]

Faggiano, L., De Zwart, D., García-Berthou, E., Lek, S. \& Gevrey, M. (2010). Patterning ecological risk of pesticide contamination at the river basin scale. Science of the Total Environment 408, 2319-2326. [CrossRef]

Fjelldal, P. G., Hansen, T., Breck, O., Sandvik R., Waagbø, R., Berg, A. \& Ørnsrud, R. (2009). Supplementation of dietary minerals during the early seawater phase increases vertebral strength and reduce the prevalence of vertebral deformities in fast-growing under-yearling Atlantic salmon (Salmo salar L.) smolt. Aquaculture Nutrition 15, 366378. [CrossRef]

Freyhof, J. \& Kottelat, M. (2018). Barbus pergamonensis. The IUCN Red List of Threatened Species; Downloaded on 30 November 2018.

Fridman, S., Bron, J. E. \& Rana, K. J. (2012). Ontogenic changes in the osmoregulatory capacity of the Nile tilapia Oreochromis niloticus and implications for aquaculture. Aquaculture 356-357, 243-249. [CrossRef]
Gaygusuz, Ö., Aydın, H., Emiroğlu, Ö., Top, N., Dorak, Z., Gaygusuz, Ç. G., Başkurt S. \& Tarkan, A. S. (2013). Length-weight relationships of freshwater fishes from the western part of Anatolia, Turkey. Journal of Applied Ichthyology 29(1), 285-287. [CrossRef]

Gracia-Lor, E., Castiglioni, S., Bade, R., Been, F., Castrignanò, E., Covaci, A., González-Mariño, I., Hapeshi, E., Kasprzyk-Hordern, B., Kinyua, J., Lai, F. Y., Letzel, T., Lopardo, L., Meyer, M. R., O'brien, J., Ramin, P., Rousis, N. I., Rydevik, A., Ryu, Y., Santos, M. M., Senta, I., Thomaidis, N. S., Veloutsou, S., Yang, Z., Zuccato, E. \& Bijlsma, L. (2017). Measuring biomarkers in wastewater as a new source of epidemiological information: Current state and future perspectives. Environment International 99, 131-150. [CrossRef]

Guzel, E. Y., Cevik, F. \& Daglioglu, N. (2018). Determination of pharmaceutical active compounds in Ceyhan River, Turkey: Seasonal, spatial variations and environmental risk assessment. Human and Ecological Risk Assessment. [CrossRef]

Hansen, T., Fjelldal, P., Yurtseva, A. \& Berg, A. (2010). Possible relation between growth and number of deformed vertebrae in Atlantic salmon (Salmo salar L.). Journal of Applied Ichthyology 26, 355-359. [CrossRef]

Harris, M. P., Henke, K., Hawkins, M. B. \& Witten, P. E. (2014). Fish is fish: the use of experimental model species to reveal causes of skeletal diversity in evolution and disease. Journal of Applied Ichthyology 30 , 616-629. [CrossRef]

Hayes, A. J., Reynolds, S., Nowell, M. A., Meakin, L. B., Habicher, J., Ledin, J., Bashford, A., Caterson, B. \& Hammond, C. L. (2013). Spinal deformity in aged zebrafish is accompanied by degenerative changes to their vertebrae that resemble osteoarthritis. PLOS ONE 8 , e75787. [CrossRef]

Gorman, K. F., Handrigan, G. R., Jin, G., Wallis, R. \& Breden, F. (2010). Structural and micro-anatomical changes in vertebrae associated with idiopathic-type spinal curvature in the curveback guppy model. Scoliosis and Spinal Disorders 5, 1-13. [CrossRef]

Hladik, M. L., Smalling, K. L. \& Kuivila, K. M. (2008). A multi-residue method for the analysis of pesticides and pesticide degradates in water using HLB solid-phase extraction and gas chromatography-ion trap mass spectrometry. The Bulletin of Environmental Contamination and Toxicology 80,139-144. [CrossRef]

Iwasaki, T., Inoue, N., Teruya, K. \& Hamasaki, K. (2018). Osteological development and deformities in hatchery-reared longtooth grouper (Epinephelus bruneus): Vertebral column, dorsal-fin supports and caudal-fin skeleton. Aquaculture Research 49, 3245-3257. [CrossRef]

Janakiram, P., Geetha, G. K., Sunil Kumar, D. \& Jayasree, L. (2018). Aetiological studies on mixed infection of Abdominal segment deformity disease (ASDD) and Enterocytozoon hepatopenaei (EHP) in cultured Litopenaeus vannamei. International Journal of Fisheries and Aquatic Studies 6, 19-26.

Jara, B., Abarca, M., Wilson, R., Krapivka, S., Mercado, A., Guiñez, R. \& Marchant, L. (2017). Qualitative analysis of cartilaginous jaw element malformation in cultured yellowtail kingfish (Seriola lalandi) larvae. Aquaculture Research 48, 4420-4428. [CrossRef]

Jawad, L., Akyol, O. \& Sağlam, C. (2017). Consecutive repetition of lordosis-kyphosis in silverside Atherina boyeri Risso, 1810 collected from a wild population in Homa Lagoon, Izmir, Turkey. Archives of Polish Fisheries 25, 117-122. [CrossRef]

Jawad, L. A. \& Ibrahim, M. (2018). Environmental oil pollution: a possible cause for the incidence of ankylosis, kyphosis, lordosis and scoliosis in five fish species collected from the vicinity of Jubail City, Saudi Arabia, Arabian Gulf. International Journal of Environmental Studies 75, 425-442. [CrossRef]

Kolarevic, J., Selset, R., Felip, O., Good, C., Snekvik, K., Takle, H., Ytteborg, E., Bæverfjord, G., Asgard, T. \& Terjesen, B. F. (2013). Influence of long-term ammonia exposure on Atlantic salmon (Salmo salar L.) parr growth and welfare. Aquaculture Research 44, 16491664. [CrossRef] 
Kottelat, M. \& Freyhof, J. (2007). Handbook of European freshwater fishes. Publications Kottelat, Cornol and Freyhof, Berlin.

Kužir, S., Maleničić, L., Stanin, D., Trbojević, T. T., Alić, I. \& Gjurčević, E. (2015). Description of head deformities in cultured common carp (Cyprinus carpio Linnaeus, 1758). Veterinarski Arhiv 85, 437-449.

López-Olmeda, J., Noble, C. \& Sánchez-Vázquez, F. (2012). Does feeding time affect fish welfare? Fish Physiology and Biochemistry 38, 143152. [CrossRef]

Luo, Y., Guo, W., Ngo, H. H., Nghiem, L. D., Hai, F. I., Zhang, J. \& Wang, X. C. (2014). A review on the occurrence of micropollutants in the aquatic environment and their fate and removal during wastewater treatment. Science of the Total Environment 473-474, 619-641. [CrossRef]

Majeed, Z., Ajab, Z., Zuberi, A., Akther, S. \& Muhammad, A. (2018). Meristic variations and skeletal deformities in natural population of mahseer fish, Tor putitora (Hamilton, 1822). Iranian Journal of Fisheries Sciences 17, 208-216.

Minguez, L., Pedelucq, J., Farcy, E., Ballandonne, C., Budzinski, H. \& Halm-Lemeille, M. P. (2016). Toxicities of 48 pharmaceuticals and their freshwater and marine environmental assessment in northwestern France. Environmental Science and Pollution Research 23, 4992-5001. [CrossRef]

Morasch, B., Bonvin, F., Reiser, H., Grandjean, D., De Alencastro, L. F., Perazzolo, C. \& Kohn, T. (2010). Occurrence and fate of micropollutants in the Vidy Bay of Lake Geneva, Switzerland. Part II: micropollutant removal between wastewater and raw drinking water. Environmental Toxicology and Chemistry 29, 1658-1668. [CrossRef]

Nguyen, N. H., Whatmore, P., Miller, A. \& Knibb, W. (2016). Quantitative genetic properties of four measures of deformity in yellowtail kingfish Seriola lalandi Valenciennes, 1833. Journal of Fish Diseases 39, $217-$ 228. [CrossRef]

Noble, C., Hernán, A., Jones, C., Damsgård, B., Flood, M. J., Midling, K. O., Roque, A., Saether, B. S. \& Yue Cottee, S. (2012). Injuries and deformities in fish: their potential impacts upon aquacultural production and welfare. Fish Physiology and Biochemistry 38, 61-83. [CrossRef]

Ogunfowokan, A. O., Oyekunle, J. A. O., Torto, N. \& Akanni, M. S. (2012). A study on persistent organochlorine pesticide residues in fish tissues and water from an agricultural fish pond. Emirates Journal of Food and Agriculture 24, 165-184.

Okamura, A., Horie, N., Mikawa, N., Yamada, Y. \& Tsukamoto, K. (2018). Influence of temperature and feeding regimes on growth and notochord deformity in reared Anguilla japonica leptocephali. Fisheries Science 84, 505-512. [CrossRef]
Pochodylo, A. \& Helbling, D. E. (2015). Target screening for micropollutants in the Hudson River Estuary during the 2015 Recreational Season, New York State Water Resources Institute.

Qu, C. S., Chen, W., Bi, J., Huang, L., \& Li, F. Y. (2011). Ecological risk assessment of pesticide residues in Taihu Lake wetland, China. Ecological Modelling, 222, 287-292. [CrossRef]

Quigley, D. T. G. (1995). A lower jaw deformity in juvenile and adult Atlantic salmon (Salmosalar L.) Bulletin of the European Association of Fish Pathologists 15, 206-209.

Raja, M., Raja, R. K., Ramkumar, R., Kavitha, M., Aiswarya, D., Deepak, P. \& Perumal P. (2016). First report on the occurrence of abnormal vertebrae-containing giant danio-fish, Devario aequipinnatus (McClelland, 1839) in Stanley Reservoir of Cauvery River Tamil Nadu (India). International Journal of Fisheries and Aquatic Studies 4, 528531.

Sato, T. (2006). Occurrence of deformed fish and their fitness-related traits in Kirikuchi charr, Salvelinus leucomaenis japonicus, the southernmost population of the genus Salvelinus. Zoological Science 23, 593-599. [CrossRef]

Sauvé, S., Aboulfadl, K., Dorner, S., Payment, P., Deschamps, G. \& Prévost, M. (2012). Fecal coliforms, caffeine and carbamazepine in stormwater collection systems in a large urban area. Chemosphere 86, 118-123. [CrossRef]

Sfakianakis, D. G., Georgakopoulou, E., Papadakis, I. E., Divanach, P., Kentouri, M. \& Koumoundouros, G. (2006). Environmental determinants of haemal lordosis in European sea bass, Dicentrarchus labrax (Linnaeus, 1758). Aquaculture 254, 54-64. [CrossRef]

UNECE. (1994). Standard Statistical Classification of Surface Freshwater Quality for the Maintenance of Aquatic Life. In: Readings in International Environment Statistics, United Nations Economic Commission for Europe: United Nations, New York and Geneva, 5364.

Yıldııım, Ş., Çoban, D., Süzer, C., Fırat, K. \& Saka, Ş. (2014). Skeletal deformities of cultured sharpsnout seabream (Diplodus puntazzo) larvae during early life development. Veterinary Journal of Ankara University 61, 267-273. [CrossRef]

Yu, H. \& Cao, W. (2016). Assessment of pharmaceutical and personal care products (PPCPs) of Dalong Lake in Xuzhou by concentration monitoring and bio-effects monitoring process. Environmental Toxicology and Pharmacology 43, 209-215. [CrossRef] 